\title{
Genetic diversity of a Daugava basin brown trout (Salmo trutta) brood stock
}

\author{
Thomas Schmidt ${ }^{1,2, *}$, Matiss Zagars ${ }^{3}$, Armands Roze ${ }^{3}$ and Ralf Schulz ${ }^{1,2}$ \\ ${ }^{1}$ Institute for Environmental Sciences, University of Koblenz-Landau, Fortstrasse 7, 76829 Landau, Germany \\ ${ }^{2}$ Eusserthal Ecosystem Research Station, University of Koblenz-Landau, Birkenthalstrasse13, 76857 Eusserthal, Germany \\ ${ }^{3}$ Institute for Environmental Solutions, Lidlauks, 4101 Priekulu Parish, Priekulu County, Latvia
}

\begin{abstract}
Genetics play an increasingly important role in the conservation of threatened fish populations. We have examined twelve microsatellite markers to determine the genetic diversity of a brood stock of brown trout from the Latvian Daugava river basin, used in a local supportive breeding program and compared diversity values to other Baltic populations. Allelic data was further inspected for indications of increased inbreeding. Additionally, we have analyzed the mitochondrial control region to classify the population within a broader phylogenetic framework. We found that the genetic diversity was comparatively low, but there was no strong evidence of high inbreeding. A newly detected mitochondrial haplotype indicates unnoticed genetic diversity of "Atlantic lineage" brown trout in the Daugava basin region. Our study provides first genetic details on resident brown trout from the Baltic Daugava river basin to improve the regional conservation management of this valuable genetic resource and contributes phylogeographically useful information.
\end{abstract}

Keywords: ex situ conservation / individual inbreeding coefficient $F$ / D-loop / effective population size $N_{\mathrm{e}} /$ salmonids

Résumé - Diversité génétique d'un stock de géniteurs de truite brune (Salmo trutta) du bassin de la Daugava. La génétique joue un rôle de plus en plus important dans la conservation des populations de poissons menacées. Nous avons examiné douze marqueurs microsatellites pour déterminer la diversité génétique d'un stock de géniteurs de truite du bassin letton de la Daugava, utilisé dans le cadre d'un programme de reproduction locale et comparé les valeurs de diversité à celles d'autres populations baltes. Les données sur les allèles ont été analysées plus à fond afin de déceler des signes d'augmentation de la consanguinité. De plus, nous avons analysé la région de contrôle mitochondrial pour classer la population dans un cadre phylogénétique plus large. Nous avons constaté que la diversité génétique était comparativement faible, mais qu'il n' y avait pas de preuves solides de consanguinité élevée. Un haplotype mitochondrial nouvellement détecté indique une diversité génétique inaperçue de la truite de "lignée atlantique" dans la région du bassin de la Daugava. Notre étude fournit les premiers détails génétiques sur la truite résidente du bassin de la Daugava baltique afin d'améliorer la gestion régionale de la conservation de cette ressource génétique précieuse et fournit des informations utiles sur le plan phylogéographique.

Mots-clés : conservation ex situ / coefficient de consanguinité individuelle $F$ / boucle D / taille effective de la population $N_{e} /$ salmonidés

\section{Introduction}

Numerous fish populations are threatened by different environmental factors and human activities (e.g. Freyhof and Brooks, 2011), and diverse measures are taken to conserve such populations. Populations involved in conservation

\footnotetext{
*Corresponding author: schmidt-th@uni-landau.de
}

programs should be genetically characterized and compared to other populations of the species to set up appropriate conservation strategies (e.g. Attard et al., 2016; Luck et al., 2003; Palsbøll et al., 2007). Such information may help to prioritize conservation strategies (Araguas et al., 2007; Fraser and Bernatchez, 2001; Luck et al., 2003; Nunney and Campbell, 1993).

Supportive breeding is a common ex situ conservation strategy, often used after or along with in situ strategies like 
habitat restoration (e.g. Anderson et al., 2013; Black et al., 2016; Hundt et al., 2015; Saura and Faria, 2011), which aims at directly increasing population size. In the ideal case, specimen for supportive breeding originate from the threatened population itself to take into account possible local adaptions and best conserve the global genetic diversity of species (e.g. George et al., 2009). However, the number of spawners in breeding programs is often restricted. Thus, typically the effective population size $N_{\mathrm{e}}$ of brood stocks is low, which may lead to adverse genetic effects, such as inbreeding depressions (e.g. Fraser, 2008; Naish et al., 2013). Genetic analyses of brood stocks (spawners or descendants) may indicate such issues early (e.g. Naish et al., 2013).

Brown trout (Salmo trutta) is a species with a high level of genetic diversity and complicated spatial patterns of genetic variability indicate a complex evolutionary history (e.g. Bernatchez, 2001; Cortey et al., 2009; Laikre, 1999; Lerceteau-Kohler et al., 2013; McKeown et al., 2010). Based on analyses of mitochondrial DNA (mtDNA) at least six major genetic lineages have been detected in different regions of the Eurasian native range of the species (Bernatchez, 2001; Cortey et al., 2009; Suarez et al., 2001; Susnik et al., 2005). The "(Northern-) Atlantic lineage" is the most widespread lineage and natively distributed from western to northern Europe. Beside this large scale variability, brown trout may show considerable regional or even local differentiation (e.g. Lehtonen et al., 2009; Palmé et al., 2013), which may indicate local adaption (Meier et al., 2011), and plays an increasingly important role in conservation (e.g. Fruciano et al., 2014; Vilas et al., 2010). Additionally, natural patterns of diversity have been altered by various human activities (Kohout et al., 2012 and citations therein) more recently, which adds further complexity. Nevertheless, in several regions and certain populations human influence on the genetic diversity of brown trout may be still absent or negligible (LerceteauKohler et al., 2013; Van Houdt et al., 2005). Although genetic diversity of brown trout has been studied frequently, genetic data on this species are still lacking for important regions within its natural distribution range, like the Baltic Daugava river basin.

Against this background, we have analyzed genetically a brood stock of brown trout to enhance a local conservation initiative in Latvia. This brood stock is used to restock and support a threatened population of resident brown trout in Virgulica creek in the Daugava river basin. Virgulica creek brown trout are mainly threatened by the loss of suitable spawning grounds caused by extensively increased dam buildings of beavers (Castor fiber). This had led to a considerable decline in population size, and several stretches of the creek have been totally without trout. To protect the fish population of Virgulica creek, spawning grounds have been restored and offspring of a locally derived brood stock of brown trout was used to repopulate the creek afterwards. These efforts were undertaken by local, private initiatives, which may be considered a common situation for conservation efforts of single, specific fish stocks. Typically, comprehensive genetic analyses, including populations outside the focal area, are far beyond the capabilities of such initiatives. However, local breeding programs may benefit from genetic analyses of the population under consideration itself and further comparisons with data from other regions - if available (cp. George et al., 2009).
To improve the Virgulica creek trout restoration efforts, we have used nuclear and mitochondrial markers and compared the genetic diversity of the brood stock to other Baltic populations. Further, we have examined the allelic data for indications of inbreeding. Finally, our study provides first genetic details on resident brown trout from the Baltic Daugava river basin and contributes new phylogeographically relevant information on brown trout from an understudied region. Overall, this study may improve the regional management of the valuable genetic diversity of brown trout in the Daugava river basin.

\section{Materials and methods}

\subsection{Location and brood stock}

Virgulica creek is a small (length ca. $20 \mathrm{~km}$ ) tributary of River Pededze, in the Daugava river basin in Latvia $\left(57.44^{\circ} \mathrm{N}\right.$, $27.33^{\circ} \mathrm{E}$ ) and a typical salmonid creek of the region (Fig. 1). The dominant land use around Virgulica creek is forestry, but also some agriculture. In the 1960/70s the creek was partly straightened for agricultural land reclamation.

In recent years the main threat to brown trout in Virgulica creek was loss of spawning grounds and habitat fragmentation caused by beaver dams. Licensed recreational angling takes place at the creek, but fishing pressure is generally low. However, illegal poaching has been observed.

Virgulica creek has a historic watermill dam $150 \mathrm{~m}$ before joining River Pededze, which presumably prevents fish upstream migrations. No stocking with foreign brown trout happened within the last 20 years and there is no indication for earlier introductions. Thus, we consider the Virgulica creek brown trout as autochthonous.

The Virgulica creek brood stock was derived from 50 wild brown trout, caught in the most downstream, largely unmodified stretch of the creek in 2009. Eggs of several randomly selected females were fertilized with the milt of the respective number of likewise randomly selected males. Thereby, all available specimen (50), regardless of phenotypic properties (e.g. size, early/late maturity), were used to conserve genetic diversity and avoid artificial selection.

\subsection{Sampling and genetic analysis}

In November 2011 adipose fin tissue of 25 specimens of the first generation offspring of the breeding program was clipped and tissue samples were preserved in $96 \%$ ethanol and stored at $-20^{\circ} \mathrm{C}$ in the lab. DNA was extracted using a modified (Wetjen et al., 2017) salt protocol (Aljanabi and Martinez, 1997).

Nuclear DNA of all 25 specimens was examined at twelve microsatellite loci in two multiplex-PCRs (Type-it Microsatellite PCR Kit, QIAGEN) and one single PCR (Tab. 1). The $5 \mu$ reaction volumes contained different volumes of the primers (Tab. 1), 1x Type-it Multiplex PCR Master Mix, 0.5x Q-Solution (QIAGEN) and $10 \mathrm{ng}$ DNA. Cycling parameters were: initial denaturation $\left(95^{\circ} \mathrm{C}, 5 \mathrm{~min}\right), 30$ cycles at $94^{\circ} \mathrm{C}$ $(30 \mathrm{~s}), 57^{\circ} \mathrm{C}(90 \mathrm{~s}), 72^{\circ} \mathrm{C}(60 \mathrm{~s})$, and final extension at $60^{\circ} \mathrm{C}$ (30 min). The loci were analyzed on an automated sequencer (CEQ 8000, Beckman Coulter) using the GenomeLab DNA Size Standard Kit (400 and 600 respectively, Beckman Coulter). 


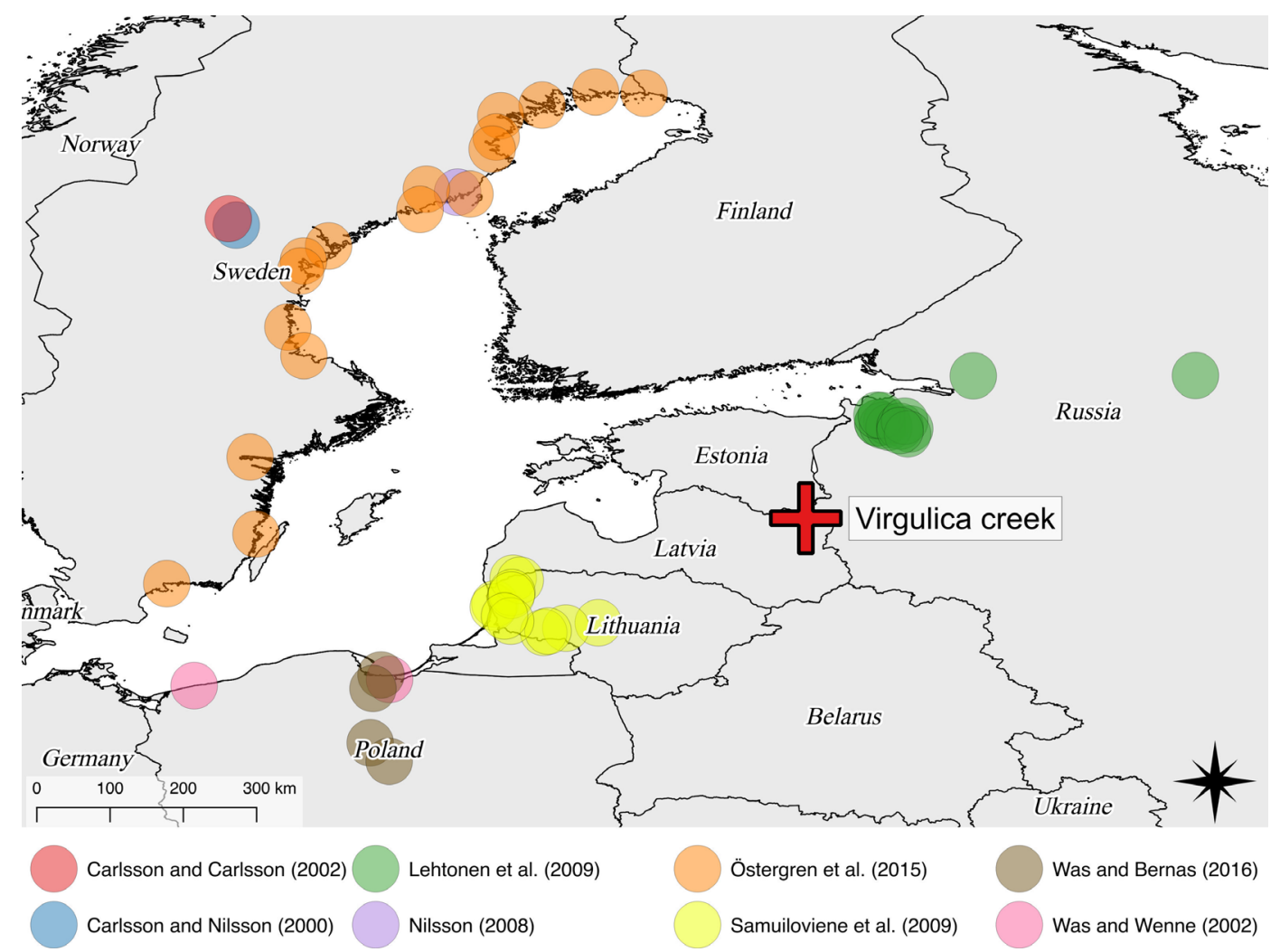

Fig. 1. Location of the Virgulica creek (red cross) in Latvia and approximate locations of non-hatchery samples from Carlsson and Carlsson (2002), Carlsson and Nilsson (2000), Lehtonen et al. (2009), Nilsson et al. (2008), Östergren et al. (2015), Samuiloviene et al. (2009), Was and Bernas (2016), and Was and Wenne (2002) (Tab. 2). Locations for Östergren et al. (2015) are indicated at the respective river outlets.

Table 1. Primer concentrations, batches, size ranges and references of the microsatellite loci.

\begin{tabular}{lllll}
\hline Locus & Concentration $[\mu \mathrm{M}]$ & PCR & Size range [bp] (Ref.) & Reference \\
\hline MST 15 & 0.05 & multiplex A & $214-224$ & Presa and Guyomard (1996) \\
Sco 216 & 1.0 & single & $329-347$ & Dehaan and Ardren (2005) \\
Ssa 85 & 0.0125 & multiplex A & $110-138$ & OReilly et al. (1996) \\
SsaA 86 & 0.025 & multiplex A & $169-241$ & King et al. $(2005)$ \\
SSOSL 85 & 0.15 & multiplex A & 194 & Slettan et al. (1995) \\
MST 60 & 0.05 & multiplex B & $97-111$ & Presa and Guyomard (1996) \\
MST 73 & 0.075 & multiplex B & $140-158$ & Presa and Guyomard (1996) \\
OMM 1310 & 0.5 & multiplex B & $175-289$ & Palti et al. (2002) \\
Sco 204 & 0.035 & multiplex B & $107-173$ & Dehaan and Ardren (2005) \\
Ssa 410 UOS & 0.5 & multiplex B & $198-324$ & Cairney et al. $(2000)$ \\
OMM 1323 & 0.05 & multiplex A & $101-206$ & Palti et al. (2002) \\
Ssa 417 OUS & 0.15 & multiplex B & $265-424$ & Cairney et al. (2000) \\
\hline
\end{tabular}

Further, the control region $(\mathrm{CR})$ of the mtDNA of 11 specimens was amplified with primers Str-L19 (5'-CCACTAGCTCCCAAAGCTA-3') and Str-H17 (5'-ACTTTCTAGGGTCCATC-3') (Bernatchez et al., 1992), as detailed in Wetjen et al. (2017). Bidirectional sequencing was done by SeqIT GmbH \& Co KG.

\subsection{Data analysis}

Prior to further analyses we checked completeness of allelic data and determined polymorphism of loci to reject uncomplete and monomorphic loci. MICRO-CHECKER Version 2.2.3 (Van Oosterhout et al., 2004) was used to test for null alleles. We determined the size range of alleles [base pairs (bp)], the number of alleles and genotypes, the allele frequencies (Supplemental Information Tab. S1), the allelic richness (AR) and observed and expected heterozygosity $\left(H_{\mathrm{obs}}\right.$ and $\left.H_{\exp }\right)$ for each locus and calculated the difference $H_{\text {exp }}-H_{\text {obs }}$ and the fixation index $F_{\text {IS }}\left[\left(H_{\text {exp }}-H_{\text {obs }}\right) / H_{\text {exp }}\right]$. Further, we tested conformity to the Hardy-Weinberg equilibrium (HWE) per locus. At population level we calculated the expected heterozygosity $H_{\mathrm{s}}$ and the means of 
T. Schmidt et al.: Knowl. Manag. Aquat. Ecosyst. 2017, 418, 55

Table 2. Number of population samples, mean number of specimens per sample, total number of specimens, number of analyzed microsatellites $\left(N_{\mathrm{MS}}\right)$, river and sea basin of sample origin, and years of sampling from eight studies from which genetic diversity data were acquired for comparison with our results on the Virgulica creek brood stock sample. Comparisons of diversity values per sample are shown in Figure 2.

\begin{tabular}{|c|c|c|c|c|c|c|}
\hline \multirow[t]{2}{*}{ Samples } & Specimens & \multirow[t]{2}{*}{$N_{\mathrm{MS}}$} & \multirow[t]{2}{*}{ River basin(s) } & \multirow[t]{2}{*}{ Sea basin(s) } & \multicolumn{2}{|c|}{ Year(s) of sampling Reference } \\
\hline & Mean (SEM) & & & & & \\
\hline 14 & $47.21(3.74)$ & 6615 & Ammerån & Bothnian Bay & 1996, 1997 & Carlsson and Nilsson (2000) \\
\hline 1 & 48 & $48 \quad 14$ & Ammerån & Bothnian Bay & 1997 & Carlsson and Carlsson (2002) \\
\hline 16 & $35.62(4.25)$ & 5709 & Luga & Gulf of Finland & 2000-2004 & Lehtonen et al. (2009) \\
\hline 1 & 49 & 498 & Sävarån & Bothnian Bay & 2005-2006 & Nilsson et al. (2008) \\
\hline 17 & $47.06(6.97)$ & 80010 & $\begin{array}{l}\text { Torneälven, Kalixälven, } \\
\text { Luleälven, Piteälven, } \\
\text { Byskeälven, Skellefteälven, } \\
\text { Sävarån, Ume-Vindelälven, } \\
\text { Oreälven, Ångermanälven, } \\
\text { Indalsälven, Ljungan, } \\
\text { Ljusnan, Dalälven, Bråvikena, } \\
\text { Emån, Mörrumsån }\end{array}$ & $\begin{array}{l}\text { Bothnian Bay, Bothnian } \\
\text { Sea, Southern Baltic Sea }\end{array}$ & $\begin{array}{l}\text { 1995, 1999, } \\
\text { 2001-2007, } 2009\end{array}$ & Östergren et al. (2015) \\
\hline 13 & $21.77(2.19)$ & 2838 & $\begin{array}{l}\text { Akmena-Dane, Bartuva, } \\
\text { Dubysa, Jura, Minija }\end{array}$ & Southern Baltic Sea & $2003-2005$ & Samuiloviene et al. (2009) \\
\hline 6 & $39.83(0.17)$ & 2395 & Vistula, Rega, hatchery & Southern Baltic Sea & 1996, 1997 & Was and Wenne (2002) \\
\hline 9 & $101.00(8.72)$ & 9097,12 & Vistula & Southern Baltic Sea & $1971,2003,2011$ & Was and Bernas (2016) \\
\hline
\end{tabular}

the above genetic diversity values per locus and specimen respectively with standard errors (SEM). For comparison of our results on $n=25$ specimens from Virgulica creek we acquired genetic diversity values for 77 Baltic population samples from Carlsson and Carlsson (2002) Carlsson and Nilsson (2000) Lehtonen et al. (2009) Nilsson et al. (2008) Östergren et al. (2015) Samuiloviene et al. (2009) Was and Bernas (2016), and Was and Wenne (2002) (Fig. 1, Tab. 2). We obtained the mean number of alleles $(n=34)$, the mean AR $(n=55), H_{\mathrm{obs}}(n=35)$ and $H_{\exp }(n=77)$ per sample.

For each specimen we derived a likelihood function of the individual inbreeding coefficient $F$ and estimated a mean $F$ by randomly sampling $1000 F$-values from the distribution of the probability density from this function. Further, we estimated the pairwise relatedness over all loci $M_{\mathrm{xy}}$ (Blouin et al., 1996) between all specimens. We used 'adegenet' v. 1.3-9.2 (Jombart, 2008), 'hierfstat' v. 0.04-10 (Goudet, 2013) and 'Demerelate' v. 0.9-3 (Kraemer and Gerlach, 2017) in R v. 3.0.2 (R Core Team, 2013).

MtDNA CR sequences were aligned and assigned to previously published haplotypes (Bernatchez, 2001; Bernatchez et al., 1992; Cortey and Garcia-Marin, 2002; Duftner et al., 2003; Kohout et al., 2012; Weiss et al., 2001) and major mtDNA lineages (Bernatchez, 2001; Bernatchez et al., 1992) using the Geneious 6.0 software (Biomatters). Haplotype diversity $h$ was estimated as $h=n /(n-1)\left(1-\sum x_{\mathrm{i}}^{2}\right)$, with sample size $n$ and frequency of haplotype $x_{\mathrm{i}}$ (Nei and Tajima, 1981). For comparison we obtained or calculated haplotype diversities from Cortey and Garcia-Marin (2002; $n=10)$, Duftner et al. $(2003 ; n=5)$, and Kohout et al. $(2012 ; n=29)$ for 44 populations with at least 10 specimens genotyped.

\section{Results}

The locus Ssa 417 UOS could not be amplified in 17 samples $(68 \%)$, while for all other loci percentage of missing data was within an acceptable range $(\leq 12 \%)$. Loci Ssa 417 UOS and
OMM 1323 were $100 \%$ monomorphic, and thus rejected, so that further analyses included allelic data from 25 individuals at 10 polymorphic loci. No evidence for null alleles was found.

For the Virgulica stock the mean number of alleles was 3.40 (SEM 0.43) and the mean AR was 3.80 (SEM 0.04). The mean $H_{\text {obs }}$ was 0.52 (SEM 0.02) and the mean $H_{\text {exp }}$ was 0.53 (SEM 0.05 ). Table 3 shows detailed characteristics per locus. All four diversity values were in the lower quartile of the respective values obtained from other studies (Fig. 2). The mean number of alleles in the reference samples ranged from 3.2 to 8.0 (median 4.72, mean 4.75, SEM 0.23) and the mean AR from 3.26 to 8.57 (median 4.61, mean 5.28, SEM 0.20). The range of $H_{\text {obs }}$ was 0.39 to 0.80 (median 0.64 , mean 0.62 , SEM 0.02 ) and 0.47 to 0.75 (median 0.66, mean 0.65, SEM 0.01) for $H_{\text {exp }}$.

The mean difference of $H_{\text {exp }}-H_{\text {obs }}$ was 0.01 (SEM 0.43), mean $F_{\text {IS }}$ was 0.04 (SEM 0.56) and significant deviation from HWE was observed at locus Ssa410UOS (Tab. 3). The genetic diversity within the population $H_{\mathrm{s}}$ was 0.53 .

Estimates of mean $F$ ranged from 0.147 (sample ID: F1459) to 0.53 (F1464). The mean $F$ of 20 specimens were below 0.33 , slightly exceeded 0.4 for two specimens $(0.41$; F1456, F1461) and were higher than 0.5 for another three (0.53; F1464, F1467, F1473) (Supplemental Information Tab. S2). Figure 3 shows a graphical representation of the likelihood functions of $F$. At population level, the mean of individual $F$-values was 0.26 (SEM 0.03). Pairwise relatedness $M_{\mathrm{xy}}$ ranged from 0.25 (F1461-F1468) to 0.83 (F1464F1470) with a mean of 0.53 (SEM 0.0065) (Fig. 4).

Based on a comparison of $247 \mathrm{bp}$ of haplotype At-s1 (310 bp; GenBank accession number M97969; Bernatchez, 2001; Bernatchez et al., 1992) and based on $401 \mathrm{bp}$ to haplotype At1 (464 bp; AF321990; Weiss et al., 2001) all mtDNA CR sequences were identical. A comparison of the full $946 \mathrm{bp}$ segments assigned eight specimens to haplotype $\mathrm{H} 2$ (1012 bp; AF273087) and two specimens to haplotype H3 (1012 bp; AF274574) in Cortey and Garcia-Marin (2002). The haplotypes $\mathrm{H} 2$ and $\mathrm{H} 3$ are identical to the haplotypes At1b and 
T. Schmidt et al.: Knowl. Manag. Aquat. Ecosyst. 2017, 418, 55

Table 3. Genetic diversity values of the $n=25$ specimens determined per locus. Bold numbers indicate significant $(p<0.0001)$ deviations from Hardy-Weinberg equilibrium.

\begin{tabular}{|c|c|c|c|c|c|c|c|c|c|c|c|}
\hline \multirow[t]{2}{*}{ Locus } & \multirow[t]{2}{*}{ Alleles } & \multirow[t]{2}{*}{ Size range [bp] } & \multirow[t]{2}{*}{ Genotypes } & \multirow[t]{2}{*}{ AR } & \multirow[t]{2}{*}{$H_{\mathrm{obs}}$} & \multirow[t]{2}{*}{$H_{\exp }$} & \multirow[t]{2}{*}{$H_{\text {exp }}-H_{\text {obs }}$} & \multirow[t]{2}{*}{$F_{\text {IS }}$} & \multicolumn{3}{|c|}{ HWE } \\
\hline & & & & & & & & & $\overline{\chi^{2}}$ & d.f. & $\bar{p}$ \\
\hline MST 15 & 3 & $221-227$ & 5 & 3.00 & 0.40 & 0.52 & 0.12 & 0.24 & 5.8164 & 3 & 0.1209 \\
\hline Sco 216 & 3 & $151-179$ & 5 & 3.00 & 0.50 & 0.57 & 0.07 & 0.13 & 2.5972 & 3 & 0.4580 \\
\hline Ssa 85 & 3 & $111-115$ & 6 & 3.00 & 0.64 & 0.62 & -0.02 & -0.02 & 1.8441 & 3 & 0.6054 \\
\hline SsAa 86 & 2 & $174-182$ & 3 & 2.00 & 0.32 & 0.36 & 0.04 & 0.12 & 0.3770 & 1 & 0.5392 \\
\hline SSOSL 85 & 3 & $178-188$ & 4 & 2.99 & 0.32 & 0.42 & 0.10 & 0.24 & 3.3179 & 3 & 0.3452 \\
\hline MST 60 & 2 & $93-97$ & 3 & 4.00 & 0.64 & 0.49 & -0.15 & -0.30 & 2.2306 & 1 & 0.1353 \\
\hline MST 73 & 2 & $141-143$ & 3 & 2.00 & 0.48 & 0.48 & 0.00 & 0.00 & 0.0000 & 1 & 1.0000 \\
\hline OMM 1310 & 4 & $182-192$ & 6 & 3.92 & 0.58 & 0.61 & 0.03 & 0.05 & 2.1724 & 6 & 0.9032 \\
\hline Sco 204 & 6 & $98-172$ & 9 & 8.49 & 0.64 & 0.62 & -0.02 & -0.03 & 4.9649 & 15 & 0.9924 \\
\hline Ssa 410 UOS & 6 & $202-254$ & 7 & 5.64 & 0.64 & 0.59 & -0.05 & -0.08 & 54.5449 & 15 & $<\mathbf{0 . 0 0 0 1}$ \\
\hline OMM 1323 & 1 & 153 & 1 & & & & & & & & \\
\hline Ssa 417 OUS & 1 & 369 & 1 & & & & & & & & \\
\hline Mean (SEM) & $3.40(0.43)$ & & $5.10(0.03)$ & $3.80(0.04)$ & $0.52(0.02)$ & $0.53(0.05)$ & $0.01(0.43)$ & $0.04(0.56)$ & & & \\
\hline
\end{tabular}

AR allelic richness, $H_{\text {obs }}$ observed heterozygosity, $H_{\text {exp }}$ expected heterozygosity, $F_{\text {IS }}$ fixation index, HWE deviation from Hardy-Weinberg equilibrium

Atld in Duftner et al. (2003). A third haplotype, represented by one specimen, was not found in any previous study. It differs from haplotypes At1b and At1d by one mutation at nucleotide position 527 (Tab. 4). This sequence was named Atlq, following the attempt of Duftner et al. (2003) to standardize haplotype nomenclature, and deposited in GenBank (KT360957).

Additionally, we compared haplotypes At1b, At1d, and At1q to a 285 bp segment at the 3' end of the CR associated to haplotype At1 (328 bp; M97968; Bernatchez et al., 1992). Haplotype At1d differs at three positions from At1, while haplotypes At1b and At1q, which are identical in this segment, differ at four positions. Differences include two insertions/ deletions in either of these cases (Tab. 4).

The estimated haplotype diversity $h$ was 0.47 , and thus within a medium range: It is between the lower quartile and the median of haplotype diversities found in populations from earlier studies $(n=44$, range 0.00 to 0.90 , mean 0.53 , SEM 0.04; Fig. 5).

\section{Discussion}

The comparison of genetic diversity values of Baltic brown trout populations based on neutral nuclear markers overall revealed that the diversity of the Virgulica creek brood stock is rather low. Low genetic diversity is often regarded as a warning signal that a population might be or become threatened by increased inbreeding or deleterious genetic drift (e.g. Naish et al., 2013 and citations therein). Thus, maintenance or establishment of high levels of genetic diversity is a common aim of conservation efforts (Saura and Faria, 2011). Nevertheless, low genetic diversity may occur in small, wild salmonid populations without preventing survival and adaption (Pujolar et al., 2016) and citations therein), so that the comparatively low genetic diversity of the Virgulica brood stock itself is not necessarily a major concern.
Direct comparisons of genetic diversity between microsatellite based studies might be affected e.g. by the selection of different markers (Ryman et al., 2006). However, this effect should be reduced at population level by averaging over a number of loci with different levels of polymorphism. The number of loci in the studies used here for comparison ranged from 5 to 14 (mean 8.1, SEM 0.25; Tab. 2). However, the necessary number of loci is disputable (Selkoe and Toonen, 2006). Further, rare alleles might be missed because of low sampling sizes, which also makes comparisons between studies difficult. Our sample of the Virgulica creek brood stock is at the lower range of sampling sizes per population used for comparison (Tab. 2). This might partly explain the comparatively low diversity found here. However, measured by the low number of 50 specimens in the parental generation, we believe that our sample is representative for the brood stock. The range of genetic diversity values compared here, might in part reflect the ecological range of Baltic brown trout (e.g. effective population sizes, life history traits, isolation, or population history, like bottlenecks), so that overall, despite methodological difficulties, we believe that this approach is helpful in providing a context for the further assessment of the Virgulica creek population.

The mean difference of $H_{\text {exp }}-H_{\text {obs }}$, the mean $F_{\text {IS }}$, and deviations from HWE, provide better evidence for inbreeding than above genetic diversity values. Both, mean $H_{\text {exp }}-H_{\text {obs }}$ and $F_{\text {IS }}$, were nearly zero. Significant deviation from HWE was found only at a single locus. Thus, all three values did not indicate significant inbreeding at the population level. In contrast we have found certain indications for inbreeding at the individual level, i.e. mean $F>0.4$, in 5 specimens $(20 \%)$. We consider this indication as weak $(0.4<F \leq 0.5)$ for two $(8 \%)$ specimens and as reasonable $(F>0.5)$ for three $(12 \%)$ specimens. Higher values of $F$ in first generation offspring may be explained by kinship within the sample or the parental generation. The mean, range and frequency distribution of $M_{\mathrm{xy}}$ in the brood stock sample match the expectations for full 

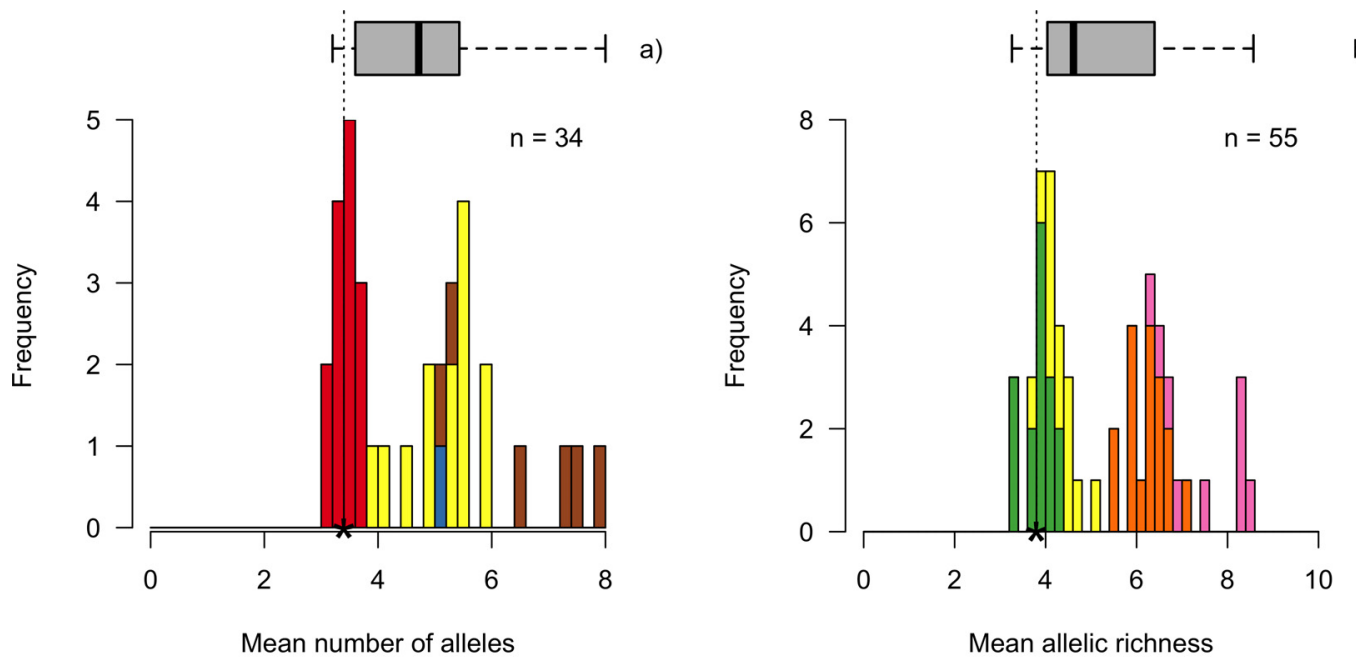

b)
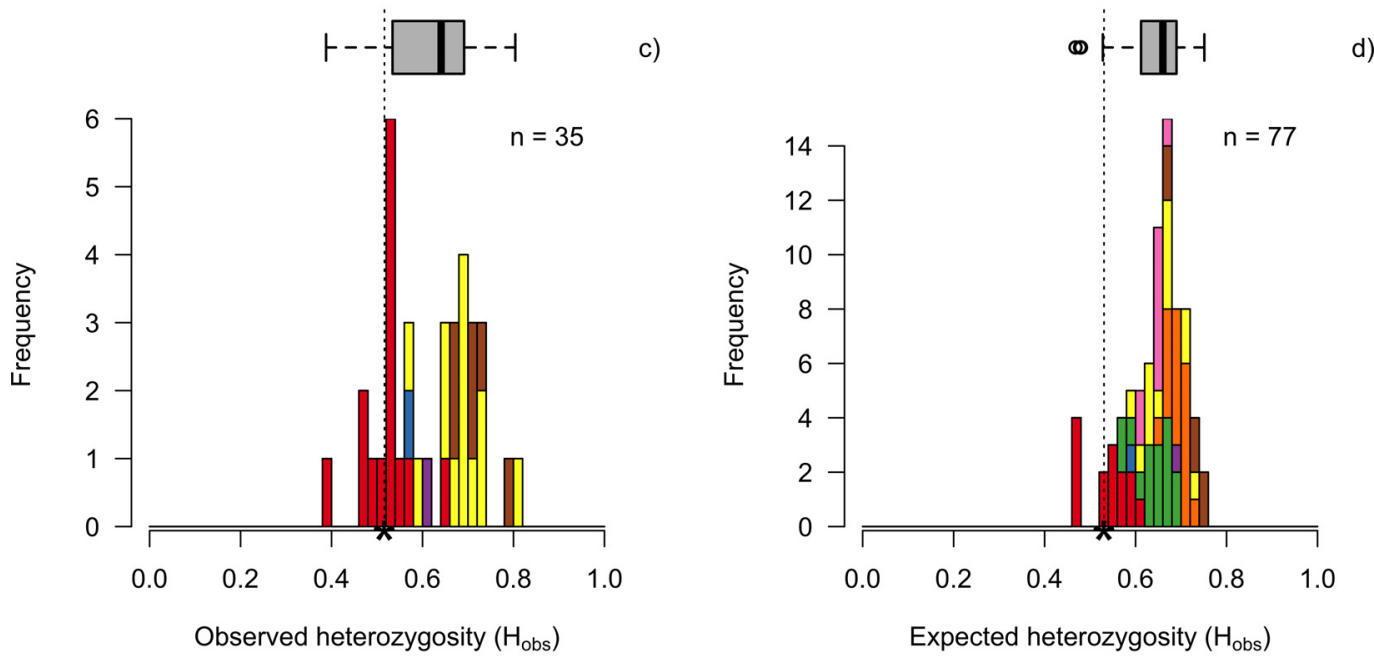

$\begin{array}{lll}\square \text { Carlsson and Carlsson (2002) } \\ \square \text { Carlsson and Nilsson (2000) } \\ \text { Lilssonen et al. (2008) } & \square \text { Östergren et al. (2015) } & \square \text { Was and Bernas (2016) } \\ \text { Silsuiloviene et al. (2009) } & \square \text { Was and Wenne (2002) }\end{array}$

Fig. 2. Frequency (bars) and distribution (boxplots) of the genetic diversity values a) mean number of alleles, b) mean allelic richness, c) observed heterozygosity, and d) expected heterozygosity of 77 samples of Baltic brown trout from Carlsson and Carlsson (2002), Carlsson and Nilsson (2000), Lehtonen et al. (2009), Nilsson et al. (2008), Östergren et al. (2015), Samuiloviene et al. (2009), Was and Bernas (2016), and Was and Wenne (2002) (Tab. 2). Asterisks and dashed lines mark the respective values of the Virgulica creek brood stock of which $n=25$ specimens were examined in the present study (a: 3.40 , b: 3.80, c: 0.52 , d: 0.53 ).

sibs (or parent-offspring pairs). Our results come very close to the findings of Blouin et al. (1996) for a breed of full siblings from wild parents in mice (Mus musculus). Thus, our sample apparently includes mostly closely related specimens. The spawners of the brood stock were mainly sampled from just several stretches of a rather small section of Virgulica creek. Thus, already this sample may have contained (half) siblings. By mixing sperm and eggs of several spawners the risk of producing offspring exclusively from one pair of siblings was minimized. However, mating of (half) siblings may also occur in the wild, especially in headwaters where effective population sizes are typically low (Hansen and Jensen, 2005). Also, at the population level, mean $F$ appears uncritically low. Thus, we believe that the proportion of specimens with indications of reasonable inbreeding of less than $15 \%$ is acceptable in a local breeding program (cp. Ruzzante et al., 2001). However, in a future perspective the Virgulica creek breeding program could benefit from conducting sib-avoidance matings to further delay inbreeding. Overall, our analyses of microsatellite data confirm that low genetic diversity itself is a rather insufficient indicator of inbreeding. Thus, aiming at increasing genetic diversity in conservation programs may not be simply justifiable by avoidance of inbreeding depressions.

Our analyses of the mtDNA CR have demonstrated that the brown trout population of Virgulica creek shows - as expected for the Daugava river basin - exclusively (northern) "Atlantic" haplotypes. Haplotypes At1b and At1d are the most common haplotypes in central and northern Europe. This is well reflected in our results: $91 \%$ of the specimens 


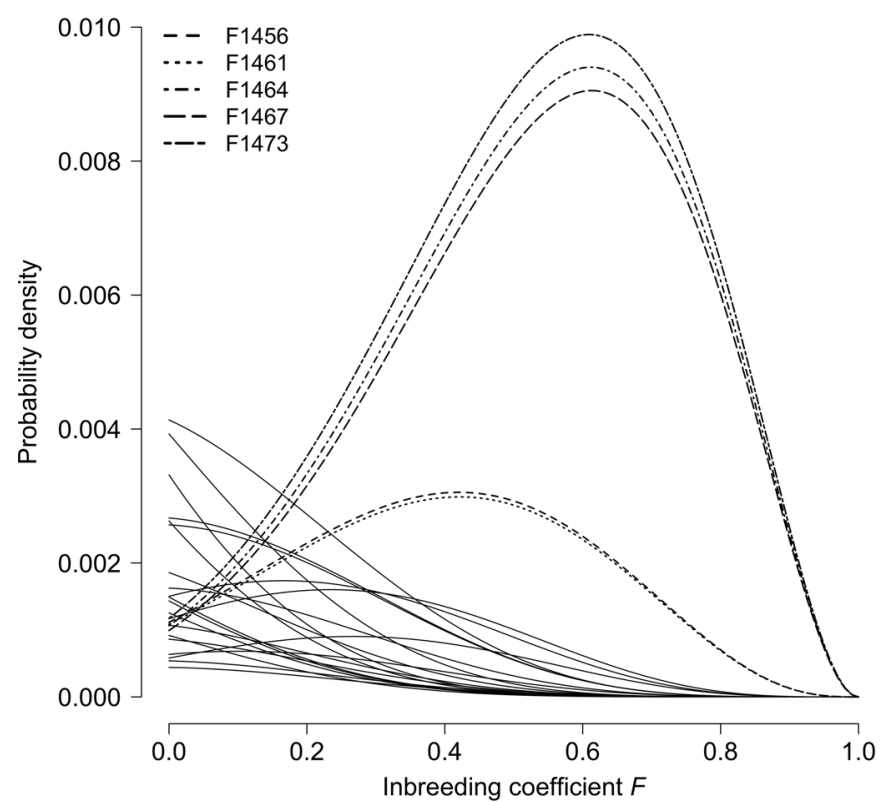

Fig. 3. Likelihood functions of the inbreeding coefficient $F$ of the $n=25$ specimens. Dashed lines indicate specimen with mean $F$-values $>0.4$ and solid lines specimen with mean $F$-values $<0.4$. Note that the maxima of the probability density for the specimens F1456 and F1461 are in the same order of magnitude $(\sim 0.4)$, while they are higher for specimens F1464, F1467, and F1473 ( 0.6) compared to mean $F$ (Supplemental Information Tab. S2).

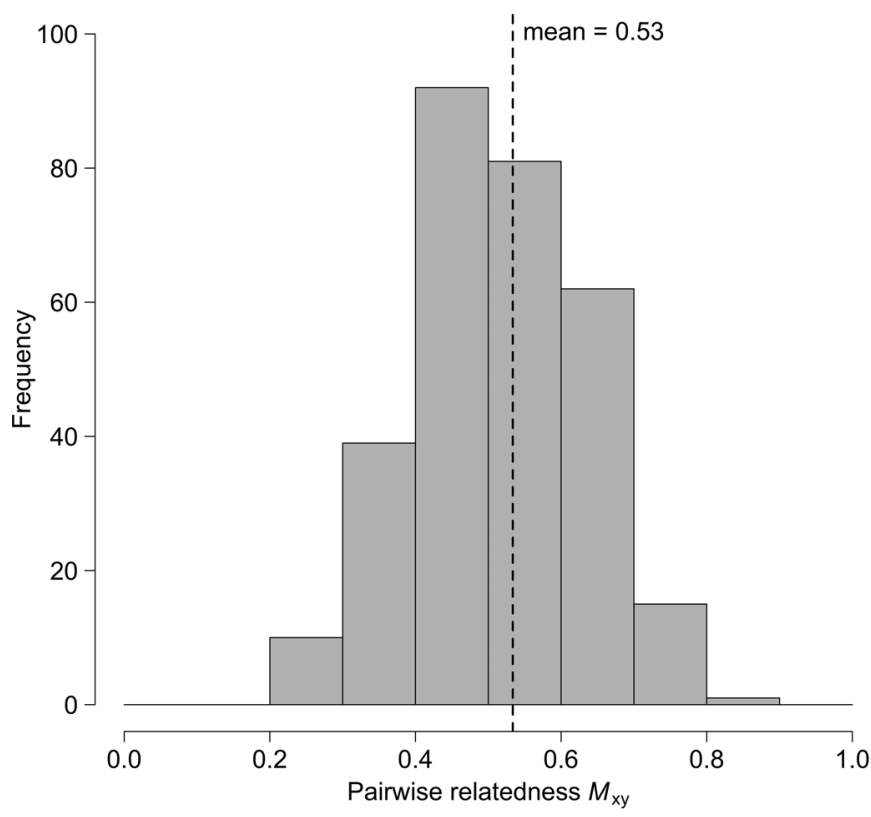

Fig. 4. Frequency of pairwise relatedness $M_{\mathrm{xy}}$ between all analyzed specimens from Virgulica creek brood stock. Dashed line indicates the mean $(0.53$, SEM 0.0065$)$ of all $M_{\mathrm{xy}}$.

Table 4. Variable base positions among the three haplotypes of the $n=11$ specimens based upon 946 bp of the mtDNA CR and additionally a 285 bp segment of the 3' end of haplotype At1 (328 bp; acc. no. M97968; Bernatchez et al., 1992). Nucleotide positions are numbered according to the reference sequence 'haplotype 2' (AF273087; Cortey and Garcia-Marin, 2002). Identity with the reference sequence is indicated with . and indels are marked with - . Number $(N)$ and relative frequency (Freq.) of each haplotype is given.

\begin{tabular}{|c|c|c|c|c|c|c|c|}
\hline \multirow[t]{2}{*}{ Haplotype name $\dagger$} & \multicolumn{5}{|c|}{ Variable sites } & \multirow[t]{2}{*}{$N$} & \multirow[t]{2}{*}{ Freq } \\
\hline & 527 & 714 & $731 \ddagger$ & $750 \S$ & 935 & & \\
\hline AT-s1|At1|H2|At1b & $\mathrm{C}$ & $\mathrm{C}$ & $\mathrm{C}$ & A & $\mathrm{A}$ & 8 & 0.73 \\
\hline AT-s1|At1|H3|At1d & . & . & . & . & $\mathrm{C}$ & 2 & 0.18 \\
\hline AT-s1|At1|-|At1q & $\mathrm{T}$ & . & . & . & . & 1 & 0.09 \\
\hline At1 -3 , end & & A & - & - & $\mathrm{C}$ & & \\
\hline
\end{tabular}

$\dagger$ The haplotype names are composed of the haplotype names of the reference sequences and separated by $\mid$, as follows: Bernatchez et al. (1992) and Bernatchez (2001) | Weiss et al. (2001) | Cortey and Garcia-Marin (2002) | Duftner et al. (2003) and this study.

$\$$ Position 731 is followed by another three cytosine nucleotides in haplotypes At1b, At1d and At1q.

$\S$ Position 750 is followed by two more adenine nucleotides in haplotypes At1b, At1d and At1q.

were assigned to either of them. One out of just eleven analyzed specimens, however, revealed a previously undescribed haplotype. This suggests that the Daugava river basin may hold undetected genetic diversity of brown trout. This assumption is supported by the variation at the $3^{\prime}$ end of the CR compared to haplotype At1 (sensu Bernatchez et al., 1992). Such previously undetected diversity in understudied regions is potentially phylogeographically relevant and lastly important to establish appropriate conservation strategies at a larger scale (e.g. Cortey and Garcia-Marin, 2002; Schenekar et al., 2014). Our study provides a first basis towards future conservation strategies for brown trout in the Daugava river basin.

From an applied perspective, our study shows the importance of comparing genetic diversity data between studies to better evaluate values measured in a single population of interest. This comparison revealed, that the genetic diversity of the Virgulica creek brood stock is relatively low. Analyses of inbreeding showed, that - despite overall low diversity - the supportive breeding procedures applied in the Virgulica creek program appear appropriate to conserve the valuable genetic diversity of brown trout at a local scale. 


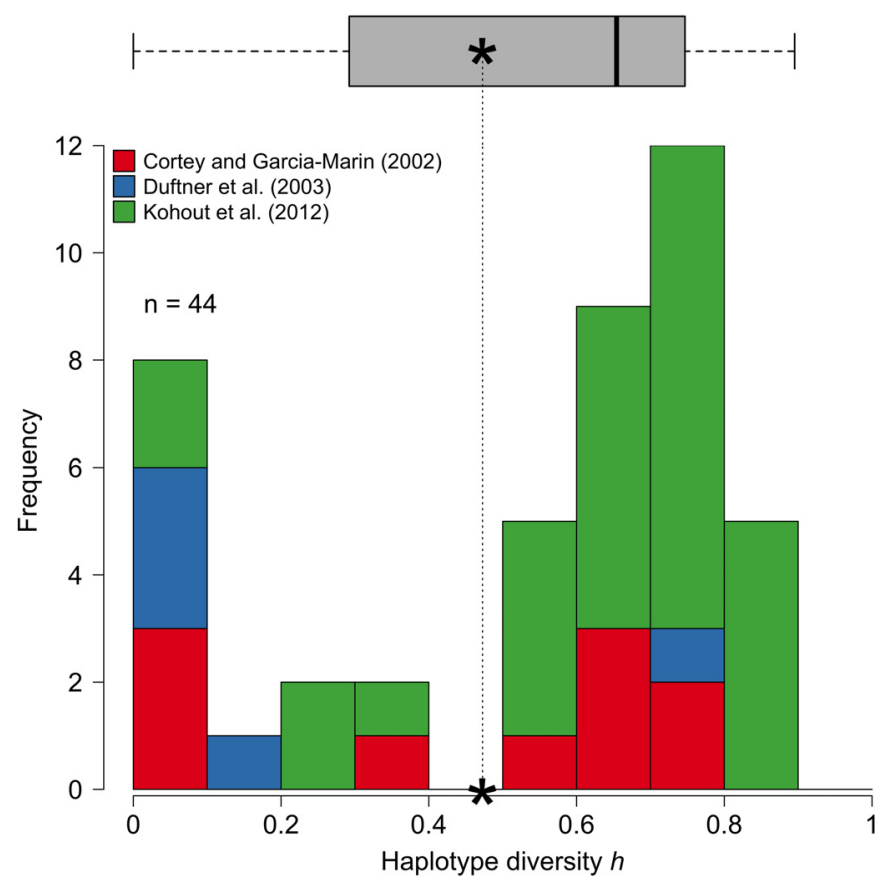

Fig. 5. Frequency (bars) and distribution (boxplot) of haplotype diversity $h$ of 44 samples of brown trout from Cortey and GarciaMarin $(2002 ; n=10)$, Duftner et al. $(2003 ; n=5)$ and Kohout et al. $(2012 ; n=29)$. Asterisks and dashed line mark the haplotype diversity of the Virgulica creek brood stock (0.47).

\section{Supplementary Material}

Supplementary tables.

The Supplementary Material is available at https://www.kmaejournal.org/10.1051/kmae/2017048/olm.

Acknowledgements. We are grateful to B. Wahl-Ermel, K. Mäck, and M. Wetjen for their support in the lab work and to an anonymous reviewer for comments on an earlier version of this manuscript.

\section{References}

Aljanabi SM, Martinez I. 1997. Universal and rapid salt-extraction of high quality genomic DNA for PCR-based techniques. Nucleic Acids Res 25: 4692-4693.

Anderson JH, Faulds PL, Atlas WI, Quinn TP. 2013. Reproductive success of captively bred and naturally spawned Chinook salmon colonizing newly accessible habitat. Evol Appl 6: 165-179.

Araguas RM, Roldán MI, García-Marín JL, Pla C. 2007. Management of gene diversity in the endemic killifish Aphanius iberus: revising operational conservation units. Ecol Freshw Fish 16: 257-266.

Attard CRM, Möller LM, Sasaki M, et al. 2016. A novel holistic framework for genetic-based captive-breeding and reintroduction programs. Conserv Biol 30: 1060-1069.

Bernatchez L. 2001. The evolutionary history of brown trout (Salmo trutta L.) inferred from phylogeographic, nested clade, and mismatch analyses of mitochondrial DNA variation. Evolution 55: 351-379.

Bernatchez L, Guyomard R, Bonhomme F. 1992. DNA sequence variation of the mitochondrial control region among geographically and morphologically remote European brown trout Salmo trutta populations. Mol Ecol 1: 161-173.
Black AN, Snekser JL, Al-Shaer L, et al. 2016. A review of the Leon springs pupfish (Cyprinodon bovinus) long-term conservation strategy and response to habitat restoration. Aquat Conserv Mar Freshw Ecosyst 26: 410-416.

Blouin MS, Parsons M, Lacaille V, Lotz S. 1996. Use of microsatellite loci to classify individuals by relatedness. Mol Ecol 5: 393-401.

Cairney M, Taggart JB, Hoyheim B. 2000. Characterization of microsatellite and minisatellite loci in Atlantic salmon (Salmo salar L.) and cross-species amplification in other salmonids. Mol Ecol 9: 2175-2178.

Carlsson J, Carlsson JEL. 2002. Micro-scale distribution of brown trout: an opportunity for kin selection? Ecol Freshw Fish 11: 234-239.

Carlsson J, Nilsson J. 2000. Population genetic structure of brown trout (Salmo trutta L.) within a northern boreal forest stream. Hereditas 132: 173-181.

Cortey M, Garcia-Marin J-L. 2002. Evidence for phylogeographically informative sequence variation in the mitochondrial control region of Atlantic brown trout. J Fish Biol 60: 1058-1063.

Cortey M, Vera M, Pla C, Garcia-Marin J-L. 2009. Northern and Southern expansions of Atlantic brown trout (Salmo trutta) populations during the Pleistocene. Biol J Linn Soc 97: 904-917.

Dehaan PW, Ardren WR. 2005. Characterization of 20 highly variable tetranucleotide microsatellite loci for bull trout (Salvelinus confluentus) and cross-amplification in other Salvelinus species. Mol Ecol Notes 5: 582-585.

Duftner N, Weiss S, Medgyesy N, Sturmbauer C. 2003. Enhanced phylogeographic information about Austrian brown trout populations derived from complete mitochondrial control region sequences. J Fish Biol 62: 427-435.

Fraser DJ. 2008. How well can captive breeding programs conserve biodiversity? A review of salmonids. Evol Appl 1: 535-586.

Fraser DJ, Bernatchez L. 2001. Adaptive evolutionary conservation: towards a unified concept for defining conservation units. Mol Ecol 10: $2741-2752$.

Freyhof J, Brooks E. 2011. European red list of freshwater fishes. Luxembourg: Publications Office of the European Union.

Fruciano C, Pappalardo AM, Tigano C, Ferrito V. 2014. Phylogeographical relationships of Sicilian brown trout and the effects of genetic introgression on morphospace occupation. Biol J Linn Soc 112: 387-398.

George AL, Kuhajda BR, Williams JD, Cantrell MA, Rakes PL, Shute JR. 2009. Guidelines for propagation and translocation for freshwater fish conservation. Fisheries 34: 529-545.

Goudet J. 2013. Hierfstat: estimation and tests of hierarchical Fstatistics. https://CRAN.R-project.org/package=hierfstat

Hansen MM, Jensen LF. 2005. Sibship within samples of brown trout (Salmo trutta) and implications for supportive breeding. Conserv Genet 6: 297-305.

Hundt M, Scharbert A, Weibel U, et al. 2015. First evidence of natural reproduction of the Allis shad Alosa alosa in the River Rhine following re-introduction measures. J Fish Biol 87: 487-493.

Jombart T. 2008. Adegenet: a R package for the multivariate analysis of genetic markers. Bioinformatics 24: 1403-1405.

King TL, Eackles MS, Letcher BH. 2005. Microsatellite DNA markers for the study of Atlantic salmon (Salmo salar) kinship, population structure, and mixed-fishery analyses. Mol Ecol Notes 5: 130-132.

Kohout J, Jaskova I, Papousek I, Sediva A, Slechta V. 2012. Effects of stocking on the genetic structure of brown trout, Salmo trutta, in Central Europe inferred from mitochondrial and nuclear DNA markers. Fish Manag Ecol 19: 252-263.

Kraemer P, Gerlach G. 2017. Demerelate: functions to calculate relatedness on diploid genetic data. https://CRAN.R-project.org/ package $=$ Demerelate 
Laikre L (ed.). 1999. Conservation genetic management of brown trout (Salmo trutta) in Europe. ("TOUTCONCERT", EU FAIR CT97-3882)

Lehtonen PK, Tonteri A, Sendek D, Titov S, Primmer CR. 2009. Spatio-temporal genetic structuring of brown trout (Salmo trutta L.) populations within the River Luga, northwest Russia. Conserv Genet 10: 281-289.

Lerceteau-Kohler E, Schliewen U, Kopun T, Weiss S. 2013. Genetic variation in brown trout Salmo trutta across the Danube, Rhine, and Elbe headwaters: a failure of the phylogeographic paradigm? $B M C$ Evol Biol 13: 176.

Luck GW, Daily GC, Ehrlich PR. 2003. Population diversity and ecosystem services. Trends Ecol Evol 18: 331-336.

McKeown NJ, Hynes RA, Duguid RA, Ferguson A, Prodoehl PA. 2010. Phylogeographic structure of brown trout Salmo trutta in Britain and Ireland: glacial refugia, postglacial colonization and origins of sympatric populations. J Fish Biol 76: 319-347.

Meier K, Hansen MM, Bekkevold D, Skaala O, Mensberg K-LD. 2011. An assessment of the spatial scale of local adaptation in brown trout (Salmo trutta L.): footprints of selection at microsatellite DNA loci. Heredity 106: 488-499.

Naish KA, Seamons TR, Dauer MB, Hauser L, Quinn TP. 2013. Relationship between effective population size, inbreeding and adult fitness-related traits in a steelhead (Oncorhynchus mykiss) population released in the wild. Mol Ecol 22: 1295-1309.

Nei M, Tajima F. 1981. DNA polymorphism detectable by restriction endonucleases. Genetics 97: 145-163.

Nilsson J, Östergren J, Lundqvist H, Carlsson U. 2008. Genetic assessment of Atlantic salmon Salmo salar and sea trout Salmo trutta stocking in a Baltic Sea river. J Fish Biol 73: 1201-1215.

Nunney L, Campbell KA. 1993. Assessing minimum viable population size: demography meets population genetics. Trends Ecol Evol 8: 234-239.

OReilly PT, Hamilton LC, McConnell SK, Wright JM. 1996. Rapid analysis of genetic variation in Atlantic salmon (Salmo salar) by PCR multiplexing of dinucleotide and tetranucleotide microsatellites. Can J Fish Aquat Sci 53: 2292-2298.

Östergren J, Nilsson J, Lundqvist H, Dannewitz J, Palm S. 2015. Genetic baseline for conservation and management of sea trout in the northern Baltic Sea. Conserv Genet 17: 177-191.

Palmé A, Laikre L, Ryman N. 2013. Monitoring reveals two genetically distinct brown trout populations remaining in stable sympatry over 20 years in tiny mountain lakes. Conserv Genet 14: 795-808.

Palsbøll PJ, Bérubé M, Allendorf FW. 2007. Identification of management units using population genetic data. Trends Ecol Evol 22: $11-16$.

Palti Y, Fincham MR, Rexroad CE. 2002. Characterization of 38 polymorphic microsatellite markers for rainbow trout (Oncorhynchus mykiss). Mol Ecol Notes 2: 449-452.

Presa P, Guyomard R. 1996. Conservation of microsatellites in three species of salmonids. J Fish Biol 49: 1326-1329.

Pujolar JM, Vincenzi S, Zane L, Crivelli AJ. 2016. Temporal changes in allele frequencies in a small marble trout Salmo marmoratus population threatened by extreme flood events. J Fish Biol 88: 1175-1190.

R Core Team. 2013. R: a language and environment for statistical computing. https://www.R-project.org/
Ruzzante DE, Hansen MM, Meldrup D. 2001. Distribution of individual inbreeding coefficients, relatedness and influence of stocking on native anadromous brown trout (Salmo trutta) population structure. Mol Ecol 10: 2107-2128.

Ryman N, Palm S, André C, et al. 2006. Power for detecting genetic divergence: differences between statistical methods and marker loci. Mol Ecol 15: 2031-2045.

Samuiloviene A, Kontautas A, Gross R. 2009. Genetic diversity and differentiation of sea trout (Salmo trutta) populations in Lithuanian rivers assessed by microsatellite DNA variation. Fish Physiol Biochem 35: 649-659.

Saura M, Faria R. 2011. Genetic tools for restoration of fish populations. J Appl Ichthyol 27: 5-15.

Schenekar T, Lerceteau-Köhler E, Weiss S. 2014. Fine-scale phylogeographic contact zone in Austrian brown trout Salmo trutta reveals multiple waves of post-glacial colonization and a predominance of natural versus anthropogenic admixture. Conserv Genet 15: 561-572.

Selkoe KA, Toonen RJ. 2006. Microsatellites for ecologists: a practical guide to using and evaluating microsatellite markers. Ecol Lett 9: 615-629.

Slettan A, Plsaker I, Lie O. 1995. Atlantic Salmon, Salmo salar, microsatellites at the SSOSL25, SSOSL85, SSOSL311, SSOSL417 loci. Anim Genet 26: 281-282.

Suarez J, Bautista JM, Almodovar A, Machordom A. 2001. Evolution of the mitochondrial control region in Palaearctic brown trout (Salmo trutta) populations: the biogeographical role of the Iberian Peninsula. Heredity 87: 198-206.

Susnik S, Schoffmann J, Weiss S. 2005. Genetic verification of native brown trout from the Persian Gulf (Catak Cay River, Tigris basin). J Fish Biol 67: 879-884.

Van Houdt JKJ, Pinceel J, Flamand M-C, et al. 2005. Migration barriers protect indigenous brown trout (Salmo trutta) populations from introgression with stocked hatchery fish. Conserv Genet 6: 175-191.

Van Oosterhout C, Hutchinson WF, Wills DPM, Shipley P. 2004. Micro-checker: software for identifying and correcting genotyping errors in microsatellite data. Mol Ecol Notes 4: 535-538.

Vilas R, Bouza C, Castro J, López A, Martínez P. 2010. Management units of brown trout from Galicia (NW: Spain) based on spatial genetic structure analysis. Conserv Genet 11: 897-906.

Was A, Bernas R. 2016. Long-term and seasonal genetic differentiation in wild and enhanced stocks of sea trout (Salmo trutta m. trutta L.) from the Vistula River, in the southern Baltic-Management implications. Fish Res 175: 57-65.

Was A, Wenne R. 2002. Genetic differentiation in hatchery and wild sea trout (Salmo trutta) in the Southern Baltic at microsatellite loci. Aquaculture 204: 493-506.

Weiss S, Schlotterer C, Waidbacher H, Jungwirth M. 2001. Haplotype (mtDNA) diversity of brown trout Salmo trutta in tributaries of the Austrian Danube: massive introgression of Atlantic basin fish - by man or nature? Mol Ecol 10: 1241-1246.

Wetjen M, Cortey M, Vera M, Schmidt T, Schulz R, Garcia-Marin JL. 2017. Occurrence of length polymorphism and heteroplasmy in brown trout. Gene Reports 6: 1-7. 